\title{
AXIAL SKELETAL MALFORMATIONS INDUCED BY SODIUM VALPROATE AND THE ROLE OF FOLIC ACID IN THEIR PREVENTION IN ALBINO RAT
}

\author{
Medhat M. Morsy \\ Anatomy Department, Faculty of Medicine, Cairo University
}

\section{INTRODUCTION}

The antiepileptic drug sodium valproate (NaVP) is a widely used mood stabilizer and seizure controlling drug. Prospective and retrospective studies have suggested that the use of sodium valproate as an antiepileptic drug during pregnancy may be related to the increased incidence of the malformations of the cardiovascular and urogenital systems (Nau et al., 1981a; Robert and Guibaud, 1982; Kock et al., 1983; Mastroiacovo et al., 1983 and Winter et al., 1987).

A fetal valproate syndrome (FVS) consisting of minor congenital anomalies has been described by Diliberti et al. (1984). In this syndrome, the dysmorphic features include epicanthal folds, strabismus, flat nasal bridge, upturned nasal tip, shallow philtrum, downturned mouth, microcephaly, radial aplasia and hyperconvex nails. Retarded psychomotor development has also been reported (Jager et al., 1987).

Skeletal defects, including both facial and appendicular skeleton, have been observed in all tested species exposed to sodium valproate in utero (mouse, rat, rabbit and monkey) by Kao et al. (1981) and Sonoda et al. (1998).

Recently, Menegola et al. (2000) reported that the administration of sodium valproate $(300 \mathrm{mg} / \mathrm{kg} /$ day) subcutaneously to pregnant rat during stage of somitogenesis $\left(9^{\text {th }}-11^{\text {th }}\right.$ day of gestation) produced malformations of axial skeleton as fusion of vertebrae and extra ribs

The results of previous workers on the teratogenic effect of sodium valproate in albino rat proved that the anomalies appeared only if fetuses were exposed to it in utero from $5^{\text {th }}$ to $15^{\text {th }}$ day of gestation (Collins et al., 1991).

While most of the teratogenic effect of NaVP is known, the mechanism of action has not been clearly established. Hansen and Grafton (1991) found marked disturbance in metabolism of folate in rats following 
administration of NaVP. A similar observation was reported by Wegner and Nau (1991a \& b).

Ehlers et al. (1996) noticed the reduction of the anomalies which induced by NaVP in case of its co-administration with the folic acid to pregnant rats. However Ubeda et al. (2001) found no value of this regime to prevent the teratogenic effect of the sodium valproate.

The objective of the present study is to make a full description of the axial skeletal anomalies induced by NaVP, to evaluate the role of folic acid in preventing these anomalies, and to determinate accurately the most expected time of gestation at which these anomalies can occur.

\section{MATERIAL AND METHODS}

Thirty adult female Albino rats weighing 150-180 gm were housed in a thermostatically maintained room $\left(T=21 \pm 1^{\circ} \mathrm{C}\right)$ with regulated cycle of light (14 hours light and 10 hours dark) and free access to food and tap water. After one week of acclimatization, each two females were caged overnight with a male. The morning when vaginal smears showed sperms was considered day 0 of gestation. Pregnant females were randomly distributed into five equal experimental groups. Each group consists of 6 pregnant females.

Group 1 control group was given saline orally.

Group II were treated on days 7 and 8 (Presomitic period) by NaVP only.

Group III were treated on days 9,10 and 11 (somitic period) by NaVP only

Group IV were treated on days 9,10 and 11 (somitic period) by NaVP and folic acid.

Group V were treated from 12 to 20 days (postsomitic period) by NaVP only.

The dose of NaVP was $400 \mathrm{mg} / \mathrm{kg} /$ day. The dose of folic was $5 \mathrm{mg} /$ $\mathrm{kg} /$ day given orally twice daily ( 3 hours before and 3 hours after NaVP administration). These drugs were given by gastric intubation and their doses were chosen according to literature data from previous works (Padmanabhan \& Hameed, 1994 and Scott et al., 1997).

At the end of gestation (20 days postcoitum) the females were sacrificed by ether. The number of implantations, resorptions, stillbirths and live fetuses were recorded. The weight and crown-rump length of live fetuses were determined. 
All fetuses were processed for axial skeletal examination by alizarin red stain method of Kimmel and Triammell (1981). Ethyl alcohol solution $96 \%$ was used for fixation and dehydration of fetuses, clearing was done by putting the fetuses in $2 \%$ solution of potassium hydroxide for six to eight days until the bones were clearly visible throughout the surrounding tissues. The fetuses were transferred to Mall's solution containing alizarin red stain (two to three drops of saturated aqueous solution of alizarin red stain were added to each $100 \mathrm{ml}$ of Mall's solution) and left overnight. Then Mall's solution was changed every six hours to wash out the excess stain from soft tissue. When the bones were clearly seen, the specimens were transferred through several changes of $50,70,80$ and $90 \%$ solution of glycerine in water. Then fetuses were stored in $100 \%$ glycerine containing few drops of formaldehyde solution to prevent fungal growth. Axial skeletal malformations were examined in each specimen by a magnifying lens.

\section{RESULTS}

No marked differences were seen between the control and treated groups as far as the number of dead fetuses and the resorptions (Table 1). The fetal weights and crown-rump length were lower in all groups treated by sodium valproate only in comparison with control group and group IV which treated by sodium valproate and folic acid (Table 2). The maximum decrease was in group III and group $V$ in which the rats were treated with NaVP only during the somitic and post somitic period.

Group I: (Control): All the fetuses showed complete development of the skull, hyoid bone, sternum, vertebrae and ribs (Figs. $1 \& 2$ ).

\section{Groups II and V:}

These two groups were used as pilot groups to evaluate the teratogenic effects of sodium valproate at presomitic and postsomitic periods. No characteristic anomalies were detected in the axial skeleton of these two groups.

\section{Group III:}

Rib anomalies of different forms were observed in the fetuses of this group, (Table 3). Fusion of ribs was found in 29 fetuses $(51.2 \%)$. The rib fusion was noticed mainly in midthoracic region, the fusion was complete (Fig. 3) or partial (Fig. 4). A Lumbar rib appeared in 12 fetuses (21.4\%), (Fig. 5). Partial absence of a rib due to non-development or malossification was found in 14 fetuses, (25\%), (Fig. 6) and complete absence of a rib was noticed in 10 fetuses, (17.9\%), (Fig. 7). Abnormal direction of ribs was evident in eight fetuses, (14.3\%), (Fig. 7). Abnormal angulation of ribs was observed in 16 fetuses, (28.6\%), (Fig. 8). 
On examination of vertebral column of fetuses obtained from this group different anomalies were found (Table 4). Fusion of two vertebrae was found in the thoracic region of 6 fetuses, $(10.8 \%)$, (Fig. 9) and in the lumbar region of three fetuses $(5.4 \%)$, (Fig. 10). Hemivertebra was observed in 10 fetuses, $(17.9 \%)$ at the lumbar region either due to maldevelopment or incomplete ossification (Figs. $10 \& 11$ ). Absence of the sacrum was noticed in 8 fetuses, (14.3\%) of this group (Fig. 11).

Sternal maldevelopment in fetuses of this group was also observed (Table 5). Complete absence of the sternum was observed in 13 fetuses, $(23.2 \%)$, (Fig. 12). Complete absence of one sternebra was found in 10 offsprings, (17.9\%), (Fig. 13). Incomplete ossification of the sternebrae was noticed in 8 fetuses, $14.3 \%$ (Fig. 13).

Development of the skull was incomplete in many fetuses which were collected from this group (Table 6). The occipital bone was incomplete in five fetuses, $8.9 \%$ (Fig. 6) and completely absent in three fetuses, $(5.4 \%$ ), (Fig. 11). Interparietal bone was incomplete in three fetuses, $(5.4 \%$ ), (Fig. 11). Deficient ossification of parietal bone was observed in three fetuses, $(5.4 \%)$, (Figs.6 \& 11). Development of frontal bone was incomplete in 4 fetuses, (7.1\%), (Fig.14).

\section{Group IV:}

In this group the fetuses showed marked reduction of the anomalies of the axial skeleton.

Anomalies of the ribs were variable (Table 3). Fusion of ribs at a small segment in four fetuses, (8.3\%), (Fig. 15). Incomplete development of ribs was noticed in three fetuses, (6.3\%), (Fig.16). Complete absence of rib was observed in two fetuses, (4.2\%), (Fig.17). Lumbar rib was found in 3 fetuses, $(6.3 \%)$, (Fig. 18). Abnormal angulation of ribs was evident in $2 \mathrm{fe}-$ tuses, (4.2\%), (Fig.15). No maldevelopment of vertebral column was found.

Sternal malformations were noticed only in a very low number of fetuses of this group (Table 5). Complete absence of the sternum was found in two fetuses $(4.2 \%$ ), (Fig. 19). Absence of one sternebra was observed in three fetuses, $(6.3 \%)$, (Fig. 20). Incomplete ossification of sternebrae was noticed in one fetus (2.1\%), (Fig. 20).

Disturbance of skull development or ossification was evident in this group in a less percentage (Table 6). Occipital bone was incomplete in three fetuses, $(6.3 \%)$, (Figs.15 \& 21). Development of parietal bone was also incomplete in two fetuses, $(4.2 \%)$, (Fig. 21$)$. 
Table (1): Number (mean \pm S.D.) of implantations, resorptions, live and dead fetuses.

\begin{tabular}{|l|c|c|c|c|c|c|}
\hline \multicolumn{2}{|c|}{} & $\begin{array}{c}\text { Group I } \\
\text { (control) }\end{array}$ & $\begin{array}{c}\text { Group } \\
\text { II }\end{array}$ & Group III & $\begin{array}{c}\text { Group } \\
\text { IV }\end{array}$ & $\begin{array}{c}\text { Group } \\
\text { V }\end{array}$ \\
\hline $\begin{array}{l}\text { Implan- } \\
\text { tations }\end{array}$ & $\begin{array}{c}\text { Total } \\
\text { Mean } \\
+ \text { S.D. }\end{array}$ & $\begin{array}{c}60 \\
10 \pm 0.9\end{array}$ & $\begin{array}{c}60 \\
10 \pm 2.0\end{array}$ & $\begin{array}{c}64 \\
10.7 \pm 1.21\end{array}$ & $\begin{array}{c}54 \\
9 \pm 0.89\end{array}$ & $\begin{array}{c}55 \\
9.2 \pm 1.17\end{array}$ \\
\hline $\begin{array}{l}\text { Resorp- } \\
\text { tions }\end{array}$ & $\begin{array}{c}\text { Total } \\
\text { Mean } \\
\pm \text { S.D. }\end{array}$ & $0.7 \pm 0.82$ & $1 \pm 0.89$ & $1 \pm 0.89$ & $0.7 \pm 0.82$ & $0.7 \pm 0.82$ \\
\hline $\begin{array}{l}\text { Live } \\
\text { fetuses }\end{array}$ & $\begin{array}{c}\text { Total } \\
\text { Mean } \\
+ \text { S.D. }\end{array}$ & 540.89 & $8.7 \pm 0.88$ & $9.3 \pm 1.03$ & $8 \pm 0.89$ & $7.7 \pm 0.55$ \\
\hline $\begin{array}{l}\text { Dead } \\
\text { fetuses }\end{array}$ & $\begin{array}{c}\text { Total } \\
\text { Mean } \\
\pm \text { S.D. }\end{array}$ & $0.3 \pm 0.52$ & $0.3 \pm 0.52$ & $0.3 \pm 0.55$ & $0.3 \pm 0.52$ & $0.8 \pm 0.88$ \\
\hline
\end{tabular}

Table (2): Crown-rump length, weight (mean \pm S.D.) and number of fetuses examined..

\begin{tabular}{|c|c|c|c|c|c|}
\hline & $\begin{array}{c}\text { Group I } \\
\text { (control) }\end{array}$ & $\begin{array}{c}\text { Group } \\
\text { II }\end{array}$ & $\begin{array}{c}\text { Group } \\
\text { III }\end{array}$ & $\begin{array}{c}\text { Group } \\
\text { IV }\end{array}$ & $\begin{array}{c}\text { Group } \\
\text { V }\end{array}$ \\
\hline $\begin{array}{c}\text { No. of fetuses } \\
\text { examined }\end{array}$ & 54 & 52 & 56 & 48 & 46 \\
\hline $\begin{array}{c}\text { Crown-tump } \\
\text { length in mm. } \\
\text { (Mean } \pm \text { S.D) }\end{array}$ & $35 \pm 2.17$ & $31 \pm 2.2$ & $25 \pm 2.09$ & $33 \pm 2.47$ & $27 \pm 2.07$ \\
\hline $\begin{array}{c}\text { Weight in gm. } \\
\text { (Mean } \pm \text { S.D) }\end{array}$ & $4.1 \pm 0.33$ & $3.6 \pm 0.32$ & $2.8 \pm 0.22$ & $3.9 \pm 0.23$ & $2.9 \pm 0.21$ \\
\hline
\end{tabular}


Table (3): The different forms of anomalies of the ribs.

\begin{tabular}{|l|c|c|c|c|c|c|}
\hline \multirow{2}{*}{} & \multicolumn{2}{|c|}{$\begin{array}{c}\text { Group I (control) } \\
(\mathrm{N}=54)\end{array}$} & \multicolumn{2}{c|}{$\begin{array}{c}\text { Group III } \\
(\mathrm{N}=56)\end{array}$} & \multicolumn{2}{c|}{$\begin{array}{c}\text { Group IV } \\
(\mathrm{N}=48)\end{array}$} \\
\cline { 2 - 7 } & $\mathrm{N}$ & $\%$ & $\mathrm{~N}$ & $\%$ & $\mathrm{~N}$ & $\%$ \\
\hline Fusion of two ribs & 0 & 0 & 29 & 51.2 & 4 & 8.3 \\
\hline Lumbar rib & 0 & 0 & 12 & 21.4 & 3 & 6.3 \\
\hline Incomplete rib & 0 & 0 & 14 & 25.0 & 3 & 6.3 \\
\hline Complete absence of a rib & 0 & 0 & 10 & 17.9 & 2 & 4.2 \\
\hline Abnormal direction & 0 & 0 & 8 & 14.3 & 0 & 0 \\
\hline Abnormal angulation & 0 & 0 & 16 & 28.6 & 2 & 4.2 \\
\hline
\end{tabular}

$\mathrm{N}=$ number of fetuses

Table (4): The different forms of anomalies of the vertebral column.

\begin{tabular}{|c|c|c|c|c|c|c|}
\hline & \multicolumn{2}{|c|}{$\begin{array}{c}\text { Group I } \\
\text { (control) } \\
(\mathrm{N}=54)\end{array}$} & \multicolumn{2}{|c|}{$\begin{array}{l}\text { Group III } \\
\qquad(N=56)\end{array}$} & \multicolumn{2}{|c|}{$\begin{array}{l}\text { Group IV } \\
(\mathrm{N}=48)\end{array}$} \\
\hline & $\overrightarrow{\mathrm{N}}$ & $\%$ & $\mathrm{~N}$ & $\%$ & $\mathrm{~N}$ & $\%$ \\
\hline Fusion of 2 vertebrae & 0 & 0 & 9 & 16.1 & 0 & 0 \\
\hline $\begin{array}{l}\text { Hemivertebrae at lumbar } \\
\text { region }\end{array}$ & 0 & 0 & 10 & 17.9 & 0 & 8.3 \\
\hline $\begin{array}{l}\text { Maldevelopment of sacral } \\
\text { vertebrae }\end{array}$ & 0 & 0 & 8 & 14.3 & 0 & 6.25 \\
\hline
\end{tabular}

Table (5): The different forms of anomalies of the sternum.

\begin{tabular}{|l|c|c|c|c|c|c|}
\hline \multirow{2}{*}{} & \multicolumn{2}{|c|}{$\begin{array}{c}\text { Group I } \\
\text { control) } \\
(\mathrm{N}=54)\end{array}$} & \multicolumn{2}{c|}{$\begin{array}{c}\text { Group III } \\
\text { (N=56) }\end{array}$} & \multicolumn{2}{c|}{$\begin{array}{c}\text { Group IV } \\
(\mathrm{N}=48)\end{array}$} \\
\cline { 2 - 7 } & $\mathrm{N}$ & $\%$ & $\mathrm{~N}$ & $\%$ & $\mathrm{~N}$ & $\%$ \\
\hline $\begin{array}{l}\text { Complete absence of the } \\
\text { sternum }\end{array}$ & 0 & 0 & 13 & 23.2 & 2 & 4.2 \\
\hline $\begin{array}{l}\text { Absence of a } \\
\text { sternebra }\end{array}$ & 0 & 0 & 10 & 17.9 & 3 & 6.3 \\
\hline $\begin{array}{l}\text { Incomplete ossification } \\
\text { of sternebrac }\end{array}$ & 0 & 0 & 8 & 14.3 & 1 & 2.1 \\
\hline
\end{tabular}


Table (6): The different forms of anomalies of the skull.

\begin{tabular}{|c|c|c|c|c|c|c|}
\hline & \multicolumn{2}{|c|}{$\begin{array}{c}\text { Group I } \\
\text { (control) } \\
(\mathrm{N}=54)\end{array}$} & \multicolumn{2}{c|}{$\begin{array}{c}\text { Group III } \\
(\mathrm{N}=56)\end{array}$} & \multicolumn{2}{c|}{$\begin{array}{c}\text { Group IV } \\
(\mathrm{N}=48)\end{array}$} \\
\cline { 2 - 7 } & $\mathrm{N}$ & $\%$ & $\mathrm{~N}$ & $\%$ & $\mathrm{~N}$ & $\%$ \\
\hline Frontal bone & 0 & 0 & 4 & 7.1 & 0 & 0 \\
\hline Parietal bone & 0 & 0 & 3 & 5.4 & 2 & 4.2 \\
\hline Interparietal bone & 0 & 0 & 3 & 5.4 & 0 & 0 \\
\hline Occipital bone & 0 & 0 & 8 & 14.3 & 3 & 0 \\
\hline
\end{tabular}

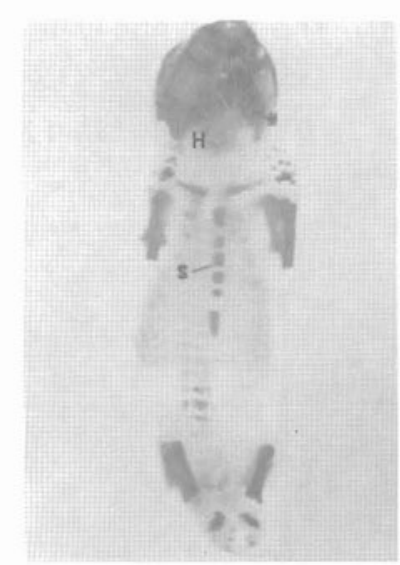

Fig. (1): A photograph of ventral view of full term rat fetus from the control group. It shows complete development of all sternebrae (S), hyoid bone $(\mathrm{H})$ and mandible $(\mathrm{M})$.

(Alizarin red stain $\times 3$ )

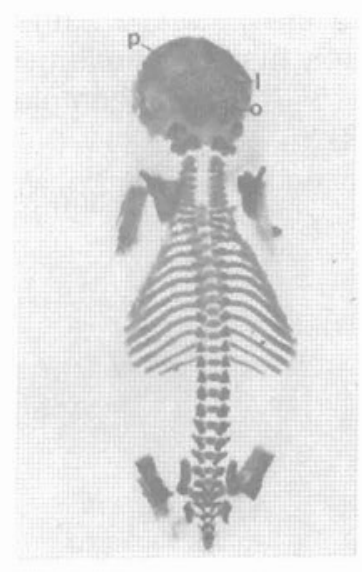

Fig. (2): A photograph of dorsal view of full term rat fetus from the control group showing complete development of parietal $(P)$, interparietal $(\mathrm{I})$ and occipital $(\mathrm{O})$ bones. Also it shows complete development of ribs and vertebral column.

(Alizarin red stain $\times 3$ ) 


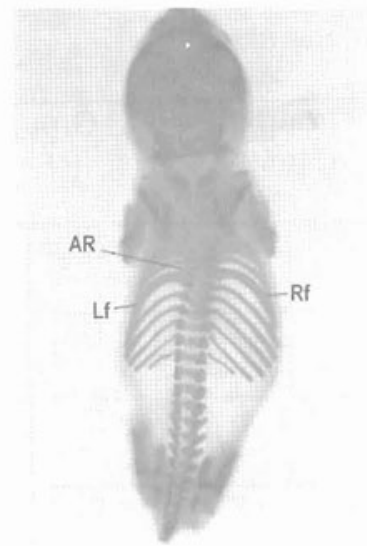

Fig. (3): A photograph of dorsal view of full term rat fetus from group III showing complete fusion of the $6^{\text {th }}$ and $7^{\text {th }}$ ribs at the right side (Rf). Also the $7^{\text {th }}$ and $8^{\text {th }}$ ribs were completely fused at the left side (Lf). The left $5^{\text {th }}$ rib was completely absent (AR),

(Alizarin red stain $\mathrm{X} 4$ )

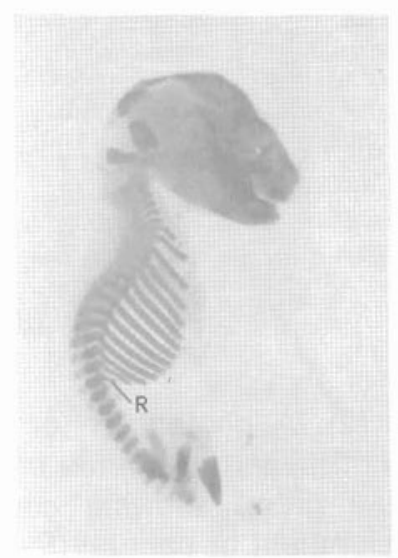

Fig. (5): A photograph of lateral view of full term rat fetus from group III showing right lumber rib $(R)$. The forelimbs were removed. (Alizarin red stain $\times 3$ )

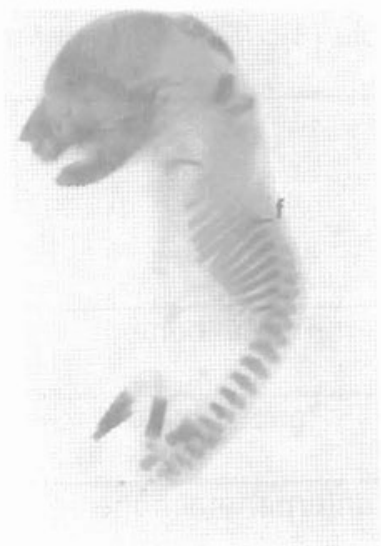

Fig. (4): A photograph of lateral view of full term rat fetus from group III showing fusion of left $6^{\text {th }}$ and $7^{\text {th }}$ ribs for a long segment (f). The forelimbs were removed.

(Alizarin red stain $\times 4$ )

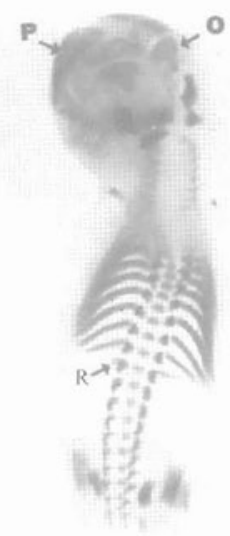

Fig. (6): A photograph of dorsal view of full term rat fetus from group III showing incomplete development of occipital bone $(\mathrm{O})$, parietal bone $(P)$ and left $13^{\text {th }}$ rib (R). The forelimbs were removed.

(Alizarin red stain $\times 4$ ) 


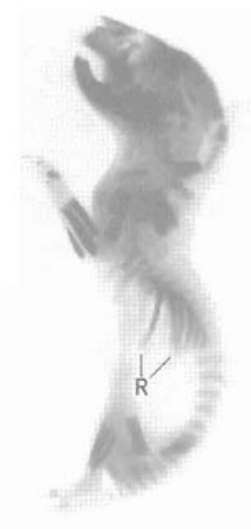

Fig. (7): A photograph of lateral view of full term rat fetus from group III showing, absence of some ribs and abnormal direction of ribs (R).

(Alizarin red stain $\times 4$ )

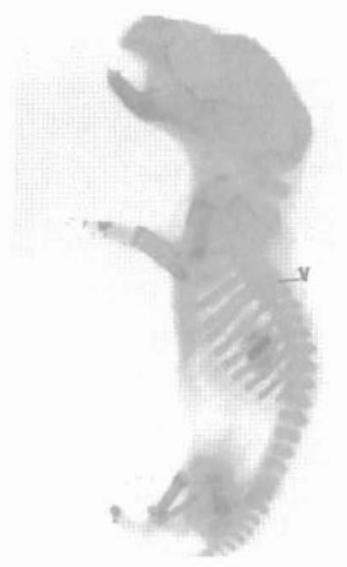

Fig. (9): A photograph of lateral view of full term rat fetus from group III showing fusion of $5^{\text {th }}$ and $6^{\text {th }}$ thoracic vertebrae $(\mathrm{V})$.

(Alizarin red stain $\times 5$ )

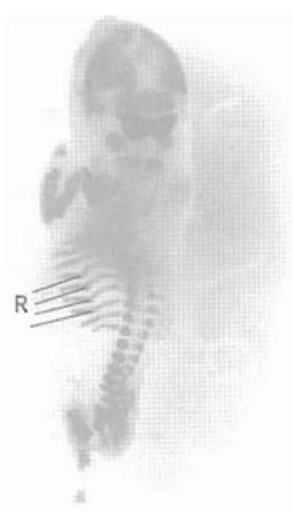

Fig. (8): A photograph of dorsolateral view of full term rat fetus from group III showing abnormal angulation of left ribs $(R)$.

\section{(Alizarin red stain $X 4$ )}

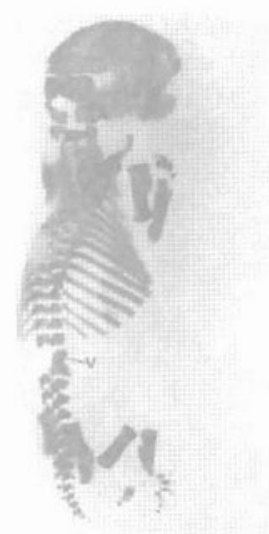

Fig. (10): A photograph of dorsolateral view of full term rat fetus from group III. showing incomplete formation and fusion of the $2^{\text {nd }}$ and $3^{\text {rd }}$ lumbar vertebrae (V).

(Alizarin red stain X 5) 


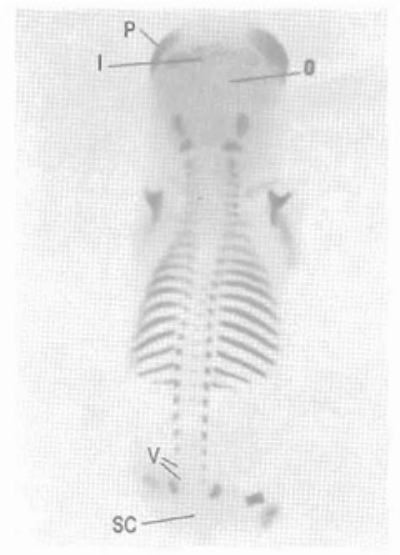

Fig. (11): A photograph of dorsal view of full term rat fetus from group III showing incomplete development of parietal bones $(P)$ interparietal bone $(\mathrm{I})$ and $5^{\text {th }}$ and $6^{\text {th }}$ lumbar vertebrae (V). Also it shows complete absence of occipital bone $(\mathrm{O})$ and sacrum (SC).

(Alizarin red stain X 4)

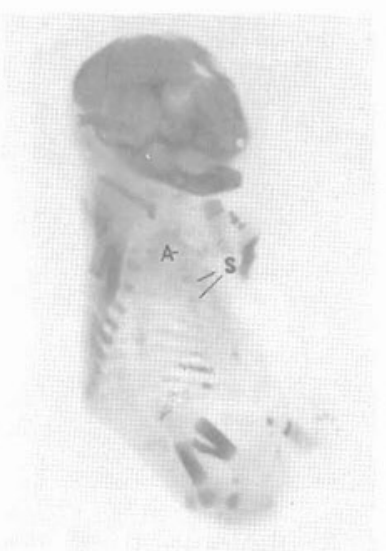

Fig. (13): A photograph of ventrolateral view of full term rat fetus from group III showing absence of one sternebra (A) and incomplete ossification of other sternebrae (S). (Alizarin red stain X 4)

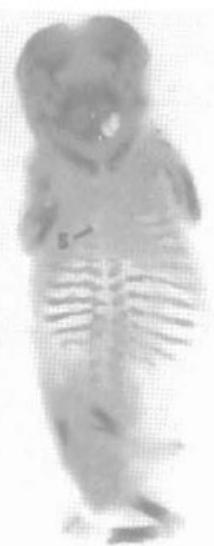

Fig. (12): A photograph of ventral view of full term rat fetus from group III showing complete absence of of the sternum (S).

(Alizarin red stain X 4)

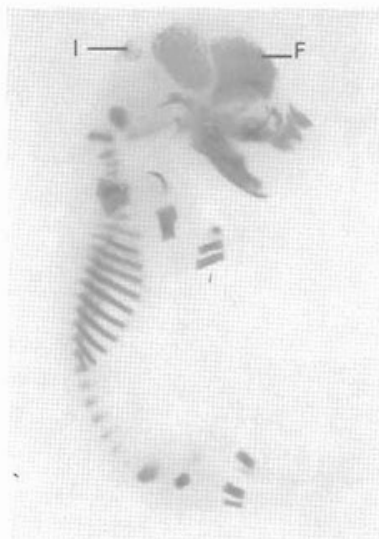

Fig. (14): A photograph of lateral view of full term rat fetus from group III showing incomplete ossification of frontal bone $(F)$ and interparietal bone (I).

(Alizarin red stain $\times 5$ ) 


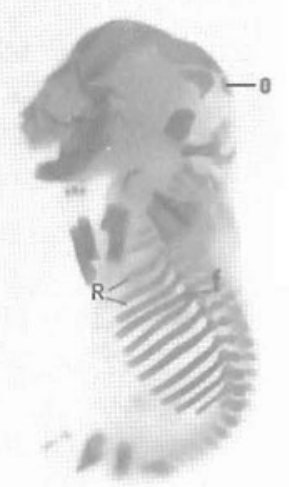

Fig. (15): A photograph of lateral view of full term rat fetus from group IV showing incomplete ossification of occipital bone (O). Aiso it shows abnormal angulation of left $3^{\text {rd }}$ and $4^{\text {th }}$ ribs (R) and dorsal fusion of left $6^{\text {th }}$ and $7^{\text {th }}$ ribs (f).

(Alizarin red stain $\times 4$ )

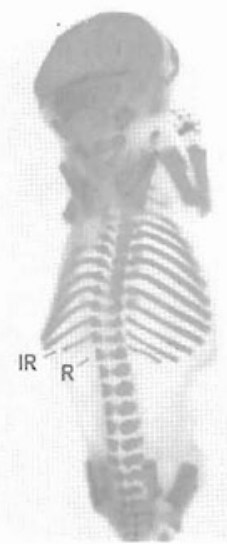

Fig. (17): A photograph of dorsal view of full term rat fetus from group IV showing incomplete left $12^{\text {th }}$ rib (IR) and complete absence of left $13^{\text {th }}$ rib $(R)$.

(Alizarin red stain $\times 3$ )

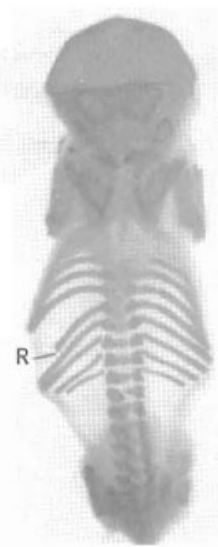

Fig. (16): A photograph of dorsal view of full term rat fetus from group IV showing incomplete left $9^{\text {th }}$ rib (R)

(Alizarin red stain X 4)

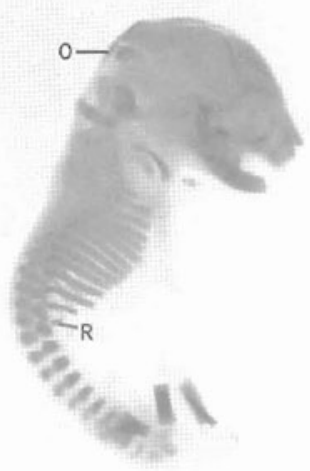

Fig. (18): A photograph of lateral view of fuli term rat fetus from group IV showing right lumbar rib (R) and incomplete development of the occipital bone $(\mathrm{O})$. Forelimbs were removed.

(Alizarin red stain $\times 3$ ) 


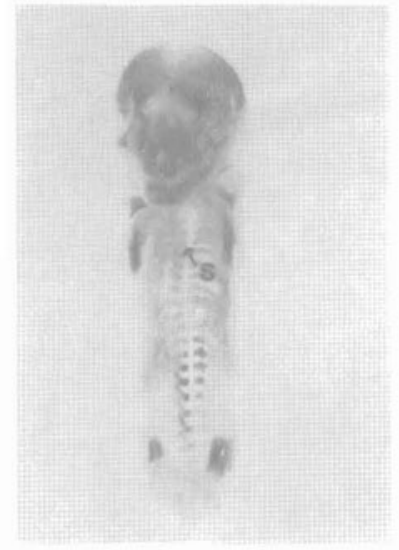

Fig. (19): A photograph of ventrolateral view of full term rat fetus from group IV showing complete absence of the ster$\operatorname{num}(\mathrm{S})$.

(Alizarin red stain X 3)

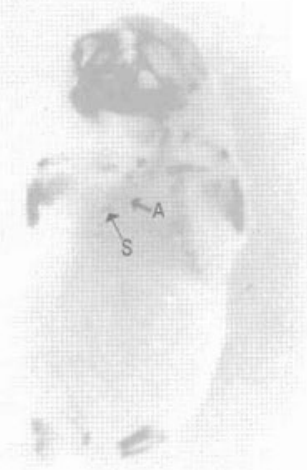

Fig. (20): A photograph of ventral view of full term rat fetus from group IV showing incomplete development of sternebrae (S) and complete absence of one sternebra (A).

(Alizarin red stain $\times 3$ )

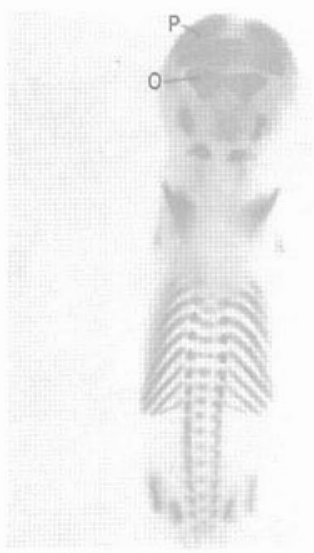

Fig. (21): A photograph of dorsal view of full term rat fetus from group IV. It shows incomplete development of parietal bones $(P)$ and occipital bone (O).

(Alizarin red stain $\times 4$ ) 


\section{DISCUSSION}

The visualization of the teratogenic effect of sodium valproate on the axial skeleton is very important as this drug is widely used to control epilepsy and as a mood stabilizer. The effect of this drug on axial skeleton of rat fetuses and the protective role of folic acid were evaluated in this work.

The results of the current work revealed reduction of weight and crown-rump length in all fetuses exposed to sodium valproate in utero at any period of gestation with maximum reduction on exposure during the somitic period. This observation is in agreement with the results of Collins et al. (1991) and Ehlers et al. (1992). The former author correlated the growth retardation to the inhibitory effect of sodium valproate on the metabolic process, but the latter attributed this retardation to the inhibitory effect of this drug on the production of growth hormone by the anterior lobe of pituitary gland.

The results of this study emphasized the teratogenic effect of sodium valproate on the axial skeleton mainly among fetuses of the third group. Rib anomalies took different figures and variable percentages. Some of these abnormalities were described by other workers. Rib fusion was partial or complete in $51.8 \%$ of the examined fetuses of the third group. Padmanabhan and Hameed (1994) found partial fusion of ribs in $21 \%$ of fetuses exposed to sodium valproate $(400 / \mathrm{kg} / \mathrm{day})$ in utero at the period from $5^{\text {th }}$ to $15^{\text {th }}$ day of gestation. However, complete fusion was not reported by any of the reviewed investigations.

Appearance of an accessory lumbar rib in $21.4 \%$ of fetuses collected from the third group in this work is in agreement with the findings of Aulthouse and Hitt (1999) who found a lumbar rib in $27 \%$ of the rat fetuses exposed to sodium valproate $(400 \mathrm{mg} / \mathrm{kg} / \mathrm{day})$ at the somitic period.

According to the findings of the current study the absence of a rib was complete in $17.9 \%$ and partial in $20.6 \%$ of the third group fetuses. Scott et al. (1997) observed only incomplete ribs in similar work. However complete absence of ribs was not reported in the available literatures. In contradiction no absence of a rib, either partial or complete, was recorded by Aulthouse and Hitt (1999) who noticed complete development of all ribs of the rat fetuses exposed in utero to the sodium valproate $(400$ $\mathrm{mg} / \mathrm{kg} /$ day) at somitic period.

In the current work the appearance of abnormal angulation of the ribs and maldirection of some of them in the third and fourth groups were not recorded before in the available literatures. 
These different forms of rib anomalies proved two points: one point is the teratogenic effect of sodium valproate on the costal process from which a rib is developed and the other point is that the rib development occurs at the somitic period.

In this work the teratogenic effect of the sodium valproate on the vertebrae were variable. Fusion of thoracic vertebrae was evidenced in the current study in $19.6 \%$ of fetuses of third group. Similar matching results were described by Padmanabhan and Hameed (1994).

In the present study the lumbar vertebrae showed hemivertebrae in $17.9 \%$ of fetuses of third group. This is in agreement with the results of Scott et al. (1997) who found lumbar hemivertebrae but at a slightly higher percentage, about $21 \%$ of rat fetuses exposed to sodium valproate in utero at somitic period. However, Padmanabhan and Ahmed (1996) did not find lumbar hemivertebrae in their similar work.

The complete absence of the sacrum in the rats fetuses of the third group were not recorded in other available similar works.

As the development of the vertebral column occurred from the sclerotome, the ventromedial part of the somite (Sadler, 2000), the anomalies of the vertebral column in this work are good indicators of the teratogenic effect of the sodium valproate on the somites. This fact is in agreement with the result of the work of Menegola et al. (2000) who found that the sodium valproate produced hemivertebrae and vertebral fusion in the rat fetuses through malformation of the somites like unequal fragmentation and abnormal shape.

In the present work, sternum was completely absent in $23.3 \%$ of fetuses collected from third group. Such finding is in agreement with results of Ubeda et al. (2001) who found complete absence of sternum in $28 \%$ of rat fetuses exposed to sodium valproate $(300 \mathrm{mg} / \mathrm{kg} /$ day) at somitic period. On the other hand, Faiella et al. (2000) did not found anomalies in the sternum of mouse fetuses exposed to NaVP in utero.

In the current study absence of a sternebra was found in $17.9 \%$ of the fetuses of the third group. On controversery, Sonoda et al. (1998) found absence of a sternebra only in $3 \%$ of mouse fetuses exposed in utero to sodium valproate ( $300 \mathrm{mg} / \mathrm{kg} /$ day) at the somitic period.

The appearance of incomplete sternebrae in the fetuses from the third group in this study is reported also by Scott et al. (1997) who correlated it to their incomplete ossification due to the disturbance of the intracellular $\mathrm{pH}$ induced by the sodium valproate. 
Aulthouse and Hitt (1999) correlated the teratogenic effect of sodium valproate on the skeletogenesis to the decrease of the mitotic activity of the chondrocytes induced by this drug. This fact may explain the anomalies in bones of axial skeleton which develop through cartilagenous ossification like vertebral column, ribs and sternum.

Skull formation in the present research was disturbed. The skull vault showed marked retardation in the development and ossification especially in the fetuses of the third group. The results of the work of Sonoda et al. (2000) and the results of this work coincided with each other in the aspect of the incomplete formation of the occipital bone in mouse and rat fetuses which were exposed to sodium valproate in utero.

The interparietal bone was incomplete in $5.4 \%$ of fetuses from third group in this work. A Similar result was reported by Faiella et al. (2000) who observed incomplete interparietal bone formation in rat fetuses exposed to sodium valproate $(400 \mathrm{mg} / \mathrm{kg} /$ day) in utero either at somitic or post somitic periods.

The incomplete formation of the parietal and the frontal bones in the rat fetuses collected from the third group in this work was not recorded before in the results of the available previous work which described the teratogenic effect of NaVP in the albino rats.

The above mentioned maldevelopment of skull vault (frontal, parietal, interparietal and occipital) may be considered as a good evidence of the teratogenic effect of sodium valproate on bones that develop by membranous ossification. Woldarczyk et al. (2002) correlated the defect in the membranous ossification to the failure of the differentiation of the mesenchymal cells into osteoblastic cells as a result of the gene mutation which induced by the sodium valproate.

The mechanism of teratogenic effect of the sodium valproate is unknown. However, many investigators reported that as the folic acid is essential for the synthesis of DNA and RNA in the growing tissues the disturbance of its metabolism induced by the sodium valproate intake may be the cause of teratogenicity of this drug (Wegner and Nau, 1991 a and b; Ehlers et al., 1996 and Puerta et al., 2001). Wegner and Nau (1991 a and $b)$ found that folate concentration in mouse embryo and maternal plasma showed normal diurnal variation. This was determined by high performance liquid chromatography. The minimum level was at night while the maximum level was by day. They noticed that the ability of sodium valproate to induce neural tube defects was reduced from $49 \%$ of living fetuses to $12 \%$ only when exposure occurred at the period of high folate concentration. 
Ehlers et al. (1996) concentrated their work on the role of the folic acid in the prevention of spina bifida in mice fetuses exposed in utero to sodium valproate at the somitic period. They observed that the coadministration of sodium valproate with folic acid reduced the rate of spina bifida in mice without altering valproate kinetics.

Also Puerta et al. (2001) reported that the co-administration of folic acid with the sodium valproate to albino rats at somitic period can prevent the teratogenic effect of this drug on the central nervous system.

On the other hand Ubeda et al. (2001) declared that the cardiovascular anomalies induced by NaVP in albino rat fetuses can not be prevented by the co-administration of folic acid.

In the present work the marked reduction of the axial skeleton anomalies in fetuses of the fourth group indicated that the mechanism of the teratogenic effect of sodium valproate is mainly through the disturbance of the folic acid metabolism.

However the persistence of some anomalies in fetuses of the fourth group in this study may be due to gene mutation as described also by Wlodarczyk, et al. (2002), or through the disturbance of the zinc metabolism as reported by Bui, et al. (2003).

Also the agreement of the results of the piolt groups of the present work with the results of Newman et al. (1993) and Menegola et al. (2000) represents an evidence of limitation of teratogenic effects of sodium valproate to the somitic period $\left(9^{\text {th }}, 10^{\text {th }}\right.$ and $11^{\text {th }}$ days) of gestation.

From this study it can be concluded that sodium valproate produces its teratogenic effect on the axial skeleton of albino rat only at the somitic period. Also the results proved that the mechanism of the teratogenic effect of the sodium valproate may be mainly through the disturbance of the folic acid metabolism. However, the utilization of sodium valproate during pregnancy must be avoided especially during the somitic period even if it is co-administrated with the folic acid due to the persistence of some anomalies in the fourth group of this work.

\section{SUMMARY}

Sodium valproate is widely used as an antiepileptic drug. It is proved to have a teratogenic effect on most of the body organs. The aim of this work was to evaluate its teratogenic effect on axial skeleton and the period of maximum susceptibility during gestation. Also this work tried to prove if 
co-administration of folic acid with sodium valproate can prevent its teratogenic effect on the axial skeleton. In this work 30 pregnant adult female albino rats weighing 150-180 gm were utilized and were divided into five groups, each consisted of six rats. The first group was a control group, second group was given sodium valproate at presomitic period $\left(7^{\text {th }}\right.$ and $8^{\text {th }}$ days of gestation), third group was given sodium valproate at somitic period $\left(9^{\text {th }}\right.$ to $11^{\text {th }}$ day), fourth group was given sodium valproate with folic acid at somitic period and the fifth group was given sodium valproate at post somitic period $\left(12^{\text {th }}\right.$ to $20^{\text {th }}$ day). The dose of sodium valproate was $(400 \mathrm{mg} /$ $\mathrm{kg} /$ day) given orally by gastric tube, while the dose of folic acid was $5 \mathrm{mg} /$ $\mathrm{kg}$ give orally twice daily (three hours before and three hours after administration of sodium valproate) in the fourth group. The pregnancy was terminated on the $20^{\text {th }}$ day of gestation. The numbers of implantation, resorption, dead and living fetuses were determined. The axial skeleton of each fetus was examined using Alizarin red stain method.

Fetuses of the third group showed many anomalies. These anomalies were; rib anomalies (rib fusion, absence of ribs, abnormal angulations and accessory lumbar rib), vertebral anomalies (vertebral fusion and hemivertebrae), sternal anomalies (absent sternum, absent one sternebra and incomplete sternebrae) and skull malformations in frontal, parietal, interparietal and occipital bones. The marked reduction of anomalies of the axial skeleton in the fourth group proved that the teratogenic effect of sodium valproate may be through the disturbance of folic acid metabolism. On the other hand the persistence of some anomalies indicated that the teratogenic effect of this drug may be through other mechanisms.

This work proved that exposure of rat fetuses in utero to sodium valproate at pre- and post-somitic periods did not induce congenital anomalies of axial skeleton.

The results of the current work revealed reduction of weight and crown-rump length in all fetuses exposed to sodium valproate in utero at any period of gestation with maximum reduction on exposure during the somitic period.

It is concluded that the use of sodium valporate should be avoided during pregnancy especially in the somitic period even if it is given with folic acid. 


\section{REFERENCES}

1. Aulthouse, A.L. and Hitt, D.C. (1999): The teratogenic effects of valproic acid in human chondrogenesis in vitro. Teratology; Mar. 59: 208217.

2. Bui, L.; Taubeneck, M. and Feber, W. (2003): Altered zinc metabolism contributes to the developmental toxicity of valproic acid. Toxicology.; Feb. 136:9-23.

3. Collins, M.D.; Walling, K.M.; Resnick, E. and Scott, W.J. (1991): Possible teratogenic effect of valproic acid. Teratology; Dec. 44: 612627.

4. Diliberti, J.; Farnon, P. and Curry, C. (1984): Fetal valproate syndrome; Is there a recognizable phenotype Am. J. Med. Genet, 19:473484.

5. Ehlers, K.; Elmazor, M.N. and Nau, H. (1996): Folic acid reduces the valproic acid-induced spina bifida rate in mice without altering valproic acid kinetics. J. Nutri.; Jun. 126(1): 67-75.

6. Ehlers, S.; Sturje, H. and Merker, H.J. (1992): Spina bifida aperta induced by volproic acid and by all-trans-retinoic acid in the mouse; distinct differences in morphology and periods of sensitivity. Teratology; Aug. 45: 145-154.

7. Faiella, A.; Wernig, M.; Consalez, G.G. and Hosick, U. (2000): A mouse model for valproate teratogenicity: parental effects and homeotic transformations. Hum.Mol. Genet.; Jan. 9 (2): 227-236.

8. Hansen, D. and Grafton, T. (1991): Lack of attenuation of valproic acid-induced effects by folic acid in rat embryos in vitro. Teratology; Jan. 43: 575-582.

9. Jager, E.; Kock, S. and Helge, H. (1987): Prognosis in fetal valproate syndrome. J. Pediatr; $111:$ 309-315.

10. Kao, J.; Brown, N.A.; Schmid, B. and Fabro, S. (1981): Teratogenicity of valproic acid. In vivo and vitro investigations. Teratog. carcinog. Mutogen; 1: 367-381.

11. Kimmel, C.A. and Triammell, C. (1981): A rapid procedure for routine double staining of cartilage and bone in fetal and adult animals. Stain Technol.; 56: 271-276. 
12. Kock, S.; Jager, E. and Helge, H. (1983): Possible teratogenic effects of valproate during pregnancy. J. Pediatr; 103: 1007-1015.

13. Mastroiacovo, P.; Bertollini, R. and Segni, G. (1983): Maternal epilepsy, valproate exposure and birth defects. Lancet; 3:1499-1504.

14. Menegola, E.; Broccia, M.L.; and Ricolfi, R. (2000): Teratogenic effects of sodium valproate in mice and rats at midgestation and at term. Teratog. Carcinog. Mutogen; 16: 97-108.

15. Nau, H.; Rating, D.; Koch, S. and Helge, H. (1981a): Valproic acid and its metabolites induced teratogenic effect in cultured mouse embryos. J. Pharmacol. Exp. Ther,; 219:768-777.

16. Newman, L.M.; Johnson, E.M. and Staples, R.E. (1993): Assessment of the effectiveness of animal developmental toxicity for human safety. Reprod. Toxicol.; Aug. 7 (4): 395-401.

17. Padmanabhan, R. and Ahmed, I. (1996): Sodium valproate augments spontaneous neural tube defects and axial skeleton malformations in mouse fetuses. Reprod. Toxicol.; Oct. 10 (5): 345-363.

18. Padmanabhan, R. and Hameed, M.G. (1994): Exencephaly and axial skeletal malformations induced by maternal administration of sodium valproate in the MF1 mouse. J. Craniofac. Genet. Dev. Biol.; Sep. 14 (3): $192-205$.

19. Robert, E. and Guibaud, P. (1982): Maternal valproic acid and congenital urogenital anomalies. Lancet; 2: 937 - 941.

20. Sadler,T.W. (2000):Langmann's medical embryology $8^{\text {th }}$ ed.,Lippincott Williams and Wilkins, Maryland,USA,Ch.8:193-194.

21. Scott, W.J.; Schreiner, C.M.; Nau, H. and Varhees, C.V. (1997): Valproate-induced axial skeleton malformation, in mice associated with reduction of intracellular $\mathrm{pH}$. Reprod. Toxicol.; Aug. 11 (4): 483-493.

22. Sonoda, T.; Ohdo, S.; Ohba, K. and Okishima, T. (1998): Teratogenic effects of sodium valproate in the JCl:ICR mouse fetus. Acta Paediatr. Jpn.; Oct. 32 (5): 502-507.

23. Sonoda, T.; Ohdo, S. and Okishima, T. (2000): Sodium valproate induced cardiovascular abnormalities in the mouse fetus, peak sensitivity of gestational day and dose dependent effects. Teratology; Aug. 62 (4): 127-132. 
24. Ubeda, N.; Alonso, E.; Achon, M.; Varela, G. and Puerta, J. (2001): Morphological changes induced by valproate and its administration concomitant with folinic acid in pregnant rats. Nutr. Hosp.; Feb. 13 (1): 41 49.

25. Wegner, C. and Nau, H. (1991a): Diumal variation of folate concentration in mouse embryo and plasma, the protective effect of folic acid on valproic acid-induced teratogenicity is time dependent. Reprod. Toxicol.; Sep. 5 (6): 465-471.

26. Wegner, C. and Nau, H. (1991b): Alternation of embryonic folate metabolism by valproic acid during organogenesis; implication for mechanism of teratogenesis. Neurology; Apr. 42 (2): 17-24.

27. Winter, R.; Donnai, D.; Burn, J. and Tucher, S. (1987): Fetal valproate syndrome. J. Med. Genet.; 24:692-695.

28. Wlodarczyk, B.C.; Craig, J.C.; Bennett, G.D. and Calvin, J.A. (2002): Valproic acid-induced changes in gene expression in a mouse model. Teratology; Dec. 66:284-291. 


\section{الملخص العربى}

تشوهات الهيكل المحوري الناتجة عن فالبورات الصوديوم ودور حامض

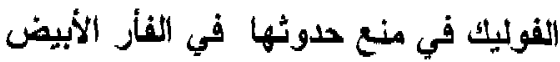 \\ مدحت محمد مرسي}

فسم التشريبح - كلية الطب - جامعة القاهرة

يستخدم فالبور ات الصوديوم بكثرة كدو اء لعلاج حالات الصرع وقد ثبت أن هـــا

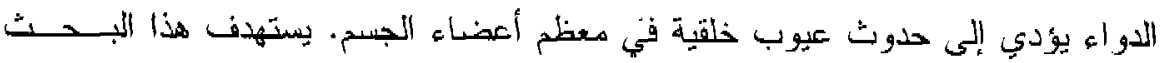

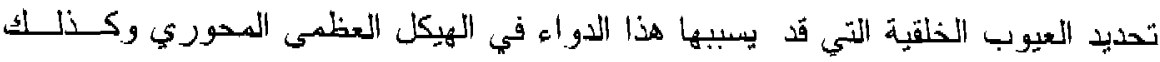

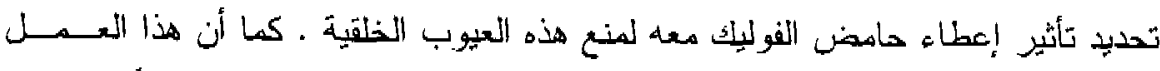

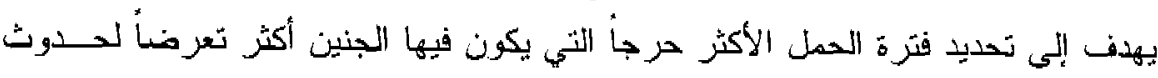

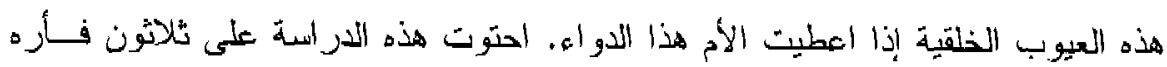

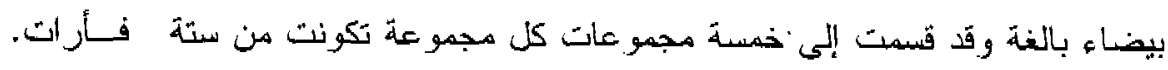

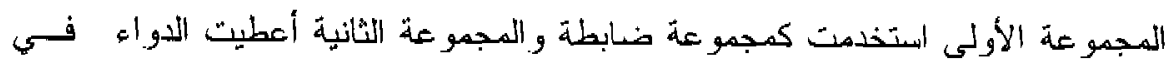

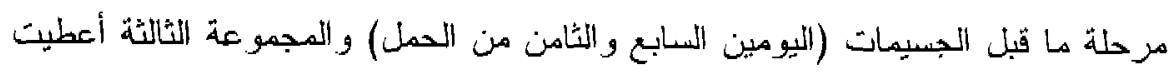

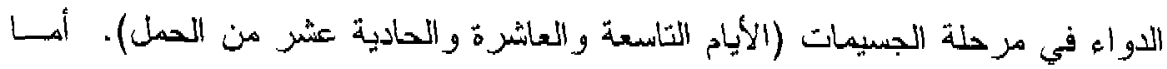

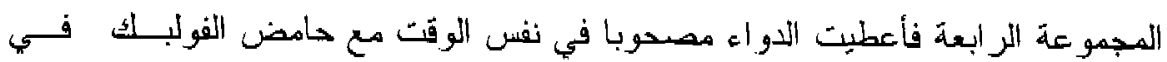

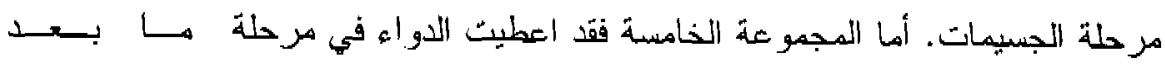

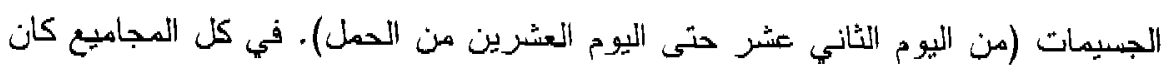

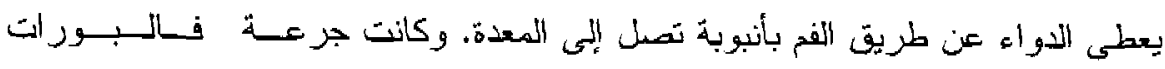

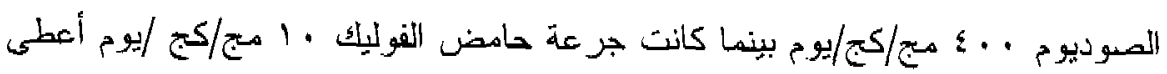

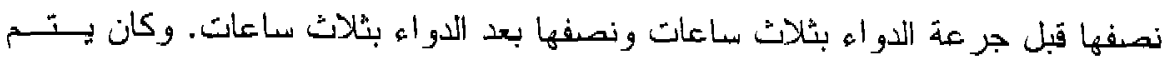

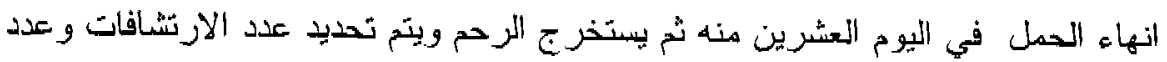

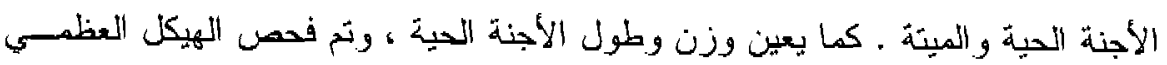

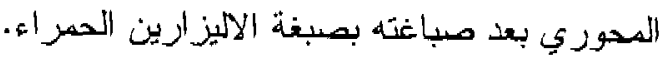




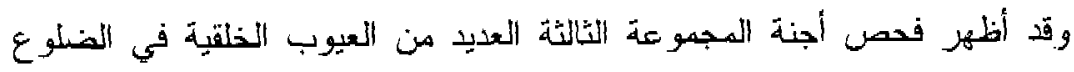

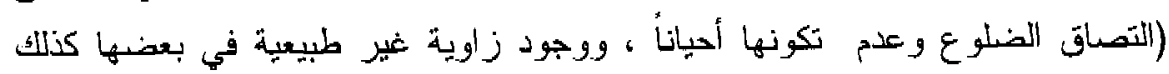

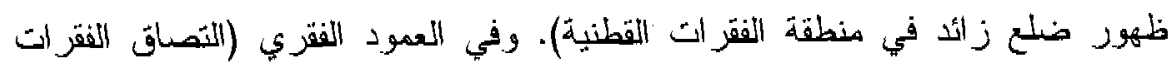

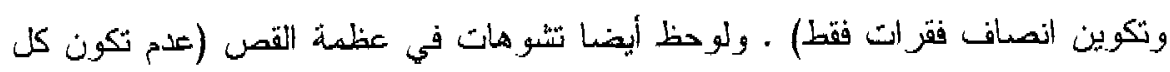

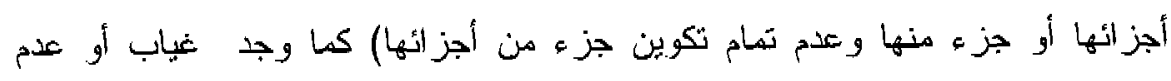

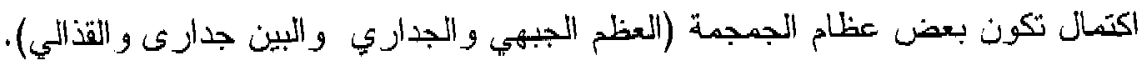
لوحظ أيضا في هذا العمل أن إعطاء حامض الفولئل العيك قلل من نسبة العيوب الخلقية

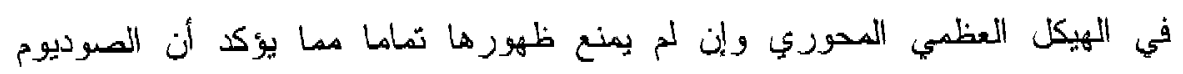

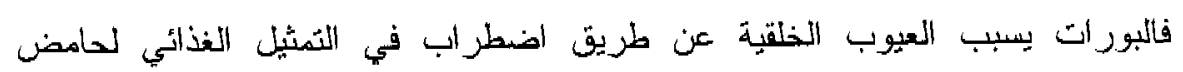

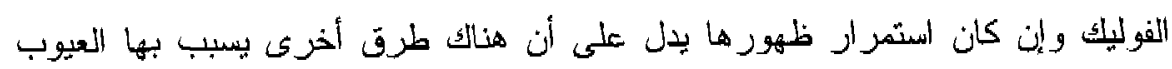

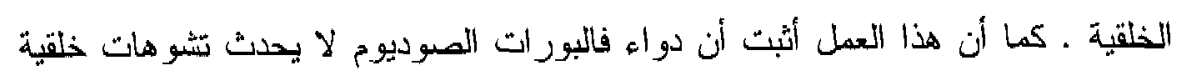
أثناء فتزة الحمل إلا في مرحلة الجسيمات.

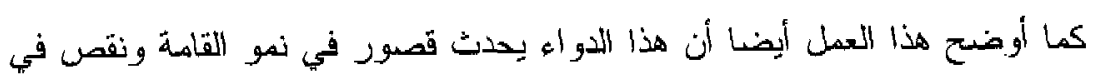
الوزن إذا أعطى أثثاء أي هرحلة من مر احل الحطل.

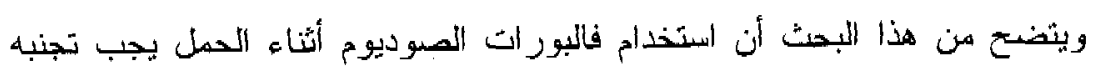

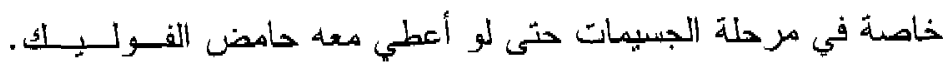

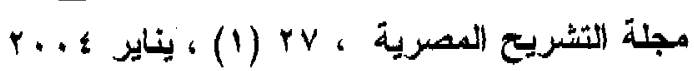

